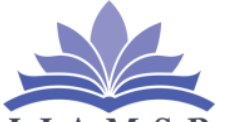

International Journal of

\title{
REVERSE TRANSFER OF L2 TO L1: THE CASE OF CODE-SWITCHING
}

\author{
Shima Ghobadi*, Mohammad Reza Talebinejad \\ Young Researchers and Elite Club, Ph.D Schoalr, Dept.of.English, Shahreza Branch, Islamic Azad \\ University, Iran
}

Shimagh1987@yahoo.com

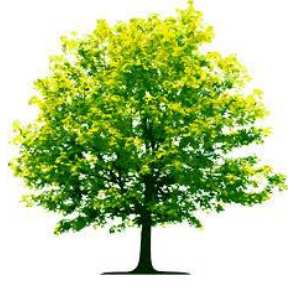

Keywords: EFL learners, Iranian learners, Transfer, codeswitching.

\begin{abstract}
A B S T RA C T
Issues related to the learners' use of the foreign language and the mother tongue (codeswitching) in the foreign language classroom and their role in language teaching and learning processes have been a common area of research. This study aimed at investigating Reverse Transfer of L2 to L1.To this end, 50 Iranian intermediate EFL learners (25 males, 25 females) at Islamic Azad University, Shahreza Branch studies in the second semester of the academic year 2016-2017 were selected through the convenience sampling method. They were then assigned randomly to the experimental and control groups. Then, a pretest was administrated to measure the learners' codeswitching in both groups. After the intervention period, an approved post-test was administered to both groups in order to check the participants' possible progress. The statistical analysis of the scores indicated that teachers and their students were found to switch codes from L2 to L1 more in the presentation phase of the lesson.In other words, teachers were found to code-switch for facilitating understanding of grammatical structures and vocabulary, maintaining discipline, motivating students, repetition for clarification, establishing effective communication, giving instruction and desire to use L1, while students were found to switch codes for maintaining flow of communication, showing personal attitude, clarifying grammatical structures or vocabulary learning. The study analysis the presence of code switching phenomena and the purpose of the occurring code switching instances. Findings have illuminative implications for language learners and teachers as well as materials developed.
\end{abstract}

Citation: Shima Ghobadi, Mohammad Reza Talebinejad (2018). Reverse Transfer Of L2 To L1: The Case Of Code-Switching. International Journal of Advanced Multidisciplinary Scientific Research (IJAMSR) ISSN:2581-4281 Vol 1, Issue 7, September, 2018, \#Art.716, pp 57-68

\section{Introduction}

With linguistic globalization as a growing trend in the modern world, most of the world's speech communities are becoming multilingual. Therefore, the contact between languages has become an important force in the everyday lives of most people. As a result, codeswitching has become a widely observed phenomenon, 


\section{International Journal of Advanced Multidisciplinary Scientific Research (IJAMSR) ISSN:2581-4281}

especially seen in bilingual, multilingual, and multicultural communities (Chung, 2006). To present the historical background of the studies on code-switching issue in ELT, it is necessary to consider the ban on the use of the learners' first language (L1) in foreign language teaching (L2). It was introduced by the direct method at the end of the nineteenth century and lasted for 120 years (Cook, 2001).

Code switching is said to be the feature that are best illustrated the difference between monolingual and multilingual speech production and reflects student competencies in two or more languages (Safont Jorda, 2005)

In ELT classrooms, code-switching may be observed either in the teachers' or the students' discourse. Nunan and Carter (2001) explained the term as "a phenomenon of switching from one language to another in the same discourse". Therefore, it is necessary for one to have at least an understanding of the functions of switching between the native and the foreign language and its underlying reasons. Sert (2005) thought that this will raise language teachers' awareness of L2 use in the classroom discourse, which "will obviously lead to better instruction by either eliminating it or dominating its use during the foreign language instruction".

Lanziti (2002) explained that the advocates of the exclusive use of the target language are losing ground and most researchers now argue in favor of a more tolerant approach to L1 use and they believe some L1 uses play a positive role in foreign language learning. Alternation between languages in the form of code switching is a widely observed phenomenon in foreign language classrooms (Sert, 2005), especially since the language behaviors of bilinguals and multilingual implies the use of two or more resources rather than a single language (Rukh, Saleem, Javeed, \& Mehmood, 2014).

In my study I look at the phenomenon of code switching in the foreign language classroom environment. The present paper offers an insight into English, foreign language classroom interactions in two different classrooms in Azad university of Shahreza. The study analysis the presence of code switching phenomena and the purpose of the occurring code switching instances.

\section{Definition of Code-Switching}

The definition of code-switching is complex as (Rukh, Saleem, Javeed, \& Mehmood, 2014).

Noted that it is problematic to define code-switching, as she mentioned that code-switching can have several different meanings and refer to whatever we want it to mean. Schendl and Wright (2011) defined codeswitching as the ability to "alternate between languages in an unchanged setting, often within the same utterance". Furthermore, Schendl and Wright (2011) stated that all speakers have the ability to use language varieties in their language repertoire. This means different things depending on speaker and the context.

Code switching (also called language mixing) is the "use of elements from two languages in the same utterance or in the same stretch of conversation" (Paradis, Genesee, \& Crago, 2011). Code switching occurs when children or adults alternate between two or more languages. The most common way young children mix two languages is by beginning a sentence in one language, then switching to another (Genesee et al., 2004).

Code-switching involves the use of multiple languages, 


\section{International Journal of Advanced Multidisciplinary Scientific Research (IJAMSR) ISSN:2581-4281}

where speakers of additional languages incorporate alternate linguistic elements into their source language. As such, two or more languages may be spoken alternately during a conversation. Chan et al (2009) usefully describe code-switching as "the intra-sentential switching of two different languages in a spoken utterance" (Chan et al, 2009).Efforts to explore sociolinguistic meaning of code-switching (CS) have occupied an important place in the study of bilinguals' communicative practices. The notion of 'code' can be explained as a neutral and objective term, which refers to a language or a variety of a language (Wang, 2006).

\section{Code-Switching in Foreign Language Learning}

In the area of second/foreign language acquisition/learning, code-switching was first seen as a linguistic behavior of developing bilinguals in bilingual or multilingual settings (Greggio \& Gil, 2007). On the other hand, recent studies carried out in monolingual foreign language classrooms showed that teachers and students make use of code-switching when interacting with each other (Antón \& Dicamilla, 1999; Gil, Garau, \& Noguera, 2012; Macaro, 2001; Mattsson \& Burenhult, 1999; Yaqubi \& Pouromid, 2013). In such classrooms, the use of the students' L1 becomes a far more practical issue. However, in classrooms where students come from different countries with various mother tongues, using their L1 in the language classroom is difficult. Therefore, the practicality of using L1 should be considered depending on the composition of the class. Simon (2001) claimed that there has been a development in the research of code-switching in foreign language learning.

Liebscher and Dailey-O'Cain (2005) suggested that foreign language learners switch back to their native language when they feel they meet obstacles in the target language conversation. Thomas (2001) maintained that in some communities code-switching is even seen as something unacceptable. However, there are researchers who see code-switching in a positive light. Sert (2005) suggested that code-switching can have a positive effect. When we code-switch we build a bridge from the known, our native language into the unknown, target language. He claims that this may have a vital and positive effect on foreign language learning.

Both positive and negative views of code switching in education have been expressed. Negative attitudes to code switching focus on repair strategies and emphasize the incomplete target-language knowledge of the learners. (Zsuzsanna, 2014)

Martin-Jones (2000) has carried out extensive research on classroom code switching and has demonstrated how widespread this phenomenon is and what a wide variety of purposes it can serve.it may reflect language practices outside the classroom, serve as an inclusive strategy where students are of varying language competences, serve to encourage students acquisition of a second, third or additional language by ensuring that they understand at least part of what is said without difficulty, and have a purpose in pedagogic discourse structuring( Gardner-Chloros, 2009).

\section{Teachers' usage of code-switching}

Inbar-Lourie (2010) deliberated if teachers should use students' L1 as a strategy for teaching foreign languages. Copland and Neokleous's (2011) interview analysis also revealed that teachers' code-switch due to different pedagogical beliefs. However, even though the reason to why they code-switched differed the teachers did not 


\section{International Journal of Advanced Multidisciplinary Scientific Research (IJAMSR) ISSN:2581-4281}

consider that a direct comparison between the L1 and L2 was advantageous. Macaro (2001) showed, through interviews, a conflict regarding the functions of teachers' usage of code-switching in relation to the development of language learning in the classroom.

The teachers' use of code-switching is not always performed consciously. In other words, the teacher is not always aware of the functions and outcomes of the codeswitching process (Sert, 2005). The best known reason behind teachers' code-switching from L2 to L1 is topic change (Mattson \& Burenhult, 1999). This reason is also replaced with facilitating understanding of grammatical structures and rules. It explains a situation where a teacher changes his/her language according to the topic that is under discussion. This is mostly observed in grammar instruction. It has been found that the teacher shifts his/her language to the students' mother tongue in dealing with particular grammar points, which are taught at that moment (Sert, 2005).

Greggio and Gil (2007) conducted a study among university students whose mother tongue was Portuguese and who were learning English as a foreign language. They indicated that the teacher switched codes from L2 to L1 to clarify understanding of the grammatical structure under analysis. Teachers may also switch codes to realize some affective functions (Zabrodjkaja, 2007). In other words, code-switching is used by the teacher in order to build close and intimate relations with the students. In this sense, it may also be named code switching for creating a supportive language environment in the classroom, maintaining discipline. Code-switching in the classroom settings is also performed by the teacher for its repetitive function. In this case, Sert (2005) explains that the teacher uses code switching to transfer the necessary knowledge to the students for clarity specifically, the following question was addressed.

'Why do EFL teachers switch their codes from L2 to L1 in foreign language classrooms?'

'Why do students switch codes from L2 to L1 in foreign language classrooms?'

\section{Literature review}

An improvement in any language can somehow result in improvements in other languages. There are different explanations and interpretations of the phenomenon known as code-switching. Switching fromL2 to L1 or vice versa seems to entail a purpose; it is a conversation keeper, a tool that allows the learner to cope with the difficulty of expressing one's thoughts in a foreign language. Moore (2002) sees code-switching as an accommodation strategy that students use to satisfy their main needs. For this reason, classroom code-switching has a lot of benefits for second language learners, as it provides a natural shortcut to content and knowledge acquisition; their bilingualism is integral to the process of accomplishing their discourse (Zimmerman, 1998, as cited in Greer, 2007, p. 5). The notion of 'code' can be explained as a neutral and objective term, which refers to a language or a variety of a language (Wang, 2006).

In the area of second/foreign language acquisition/learning, code-switching was first seen as a linguistic behavior of developing bilinguals in bilingual or multilingual settings (Greggio \& Gil, 2007).

On the other hand, recent studies carried out in monolingual foreign language classrooms showed that teachers and students make use of code-switching when interacting with each other (Antón \& Dicamilla, 1999; 


\section{International Journal of Advanced Multidisciplinary Scientific Research (IJAMSR) ISSN:2581-4281}

Gil, Garau, \& Noguera, 2012; Macaro, 2001; Mattsson \& Burenhult, 1999; Yaqubi \& Pouromid, 2013).

Mesthrie, Swann, Deumert and Leap (2010, p. 163) state that code-switching has not always been a field of serious study. The type of conversation that we call code-switching today was previously known as a bilingual's way to choose when s/he wanted to use a certain language. S/he could use one language on a certain occasion and another language on another occasion. According to Gumperz and Hernandez-Chavez (1974, p. 581) other terms can be used for codeswitching, related terms are for instance: code shifting and code mixing. Simon (p. 314) suggests that codeswitching in foreign language classrooms is much more complex to scrutinize than code-switching in social settings. The pupils in the foreign language classroom often have vague knowledge of the target language compared to bilinguals in a social setting. There is indeed a difference between code-switching in educational settings and in social settings. According to Wei and Martin (2009, p. 117) code-switching in educational settings is often seen as unsuitable and wrong, while code-switching in social contexts is seen as something natural and a part of bilingual speech.

Macaro (2014) suggests that there are two types of classrooms in terms of code switching functions: 1) classrooms where code switching is merely used for language comparison or explanation of lexical and grammatical structures of target language and 2) communicative classrooms, where code switching is used some communicative purpose, such as topic switch, socializing or expressing emotions.

\section{Methodology}

\section{Design and Context of the Study}

The data consists of transcribed audio recordings of the English classes attended in the two different classes in order to examine the actual use of code switching.In the present study I will analysis two English lessons. The classroom recordings are about 40 minutes long and were audio recorded, placed in different parts of the class. Classroom observations are accompanied also by field- notes used for descriptive information that will not be able to understand from the audio recording. As it was done while the session was running at the university during the academic year, intact classes were used. The study was done at Islamic Azad University, Shahreza Branch with a selection of students of TEFL and English translation.

\section{Participants}

The participants of the current study were 50 B.A. students of TEFL and translation studies at the intermediate level, with their age ranging from 19-29 and the English teachers of these classes at Islamic Azad University, Shahreza Branch in the second semester of the academic year 2016-2017. The participants were selected from 80 individuals who sat for the Oxford Placement Test (OPT) and were qualified as intermediate learners.

\section{Materials and Instruments}

The research materials and instruments consisted of the vocabulary level test, Audio recording and a questionnaire based on a five-point Likert scale as follows. 


\section{International Journal of Advanced Multidisciplinary Scientific Research (IJAMSR) ISSN:2581-4281}

\section{Oxford Placement Test}

In conducting this research, the researcher used the Oxford Placement Test (OPT), which is a standard test to determine the English proficiency level of the students. The multiple-choice test consists of 30 close passages, vocabulary, structure, and pronunciation items. After administering the test, the results were evaluated based on the OPT associated rating levels chart and those who obtained 20 or more on the test were judged as the intermediate learners.

\section{Vocabulary Level Test}

A vocabulary test was designed to examine the participants' knowledge of vocabulary items. The test items were selected for standardized proficiency tests such as the OPT. Then, a 30 multiple-choice item test was prepared and pilot tested with a sample of learners $(n=25)$ who were similar to those participating in the study. The test consisted of 10 closed test items and 20 multiple-choice items. The results of Cronbach's alpha analysis showed that the test was reliable $(\alpha=0.83)$. The content validity of the test was evaluated through expert opinions by TEFL specialists.

\section{Background Questionnaire}

In order to gather background information about the participants, a questionnaire was administered to students who used code switching to communicate in their daily life. The questionnaire consisted of 18 questions about the amount of the time that they used code switching in their speaking. The results obtained were used in the selection process.

\section{Data Collection Procedure}

All participants of the study $(\mathrm{n}=80)$ were given a language proficiency test in order to ensure their homogeneity in terms of their language proficiency. The learners whose scores on the OPT felt at the intermediate level, based on the standard chart were selected to participate in the main study and were randomly divided into two groups of 25, namely, experimental and control. A 30-item pre-validated vocabulary test as the pretest was also administered to the control and the experimental groups before the treatment in order to make sure they were not significantly different at the outset.

Moreover, as the study concentrated on learning the meaning of words via code switching and in order to clarify the objectives, there was a briefing session for the experimental group. To apply the treatment to the experimental group, the participants were taught four sessions and during the instruction the teacher and students use code switching for explaining the meaning of words. It should be mentioned that during these sessions the control group was taught the same passage in the conventional way through the printed text and the teacher and students didn't use code switching and they used target language. The learners in the experimental and control groups were asked to not share their information with one another. After four sessions of vocabulary teaching via code switching, a vocabulary posttest, similar to the pretest, was administered to both experimental and control groups.

\section{Data Analysis Procedure}

Using descriptive statistics, the participants who met the requirements, based on the emerging patterns of scores 


\section{International Journal of Advanced Multidisciplinary Scientific Research (IJAMSR) ISSN:2581-4281}

obtained from the OPT as the placement test, were selected. As well, to pull in the participants homogeneous in terms of their knowledge of vocabulary, a validated pretest was administered and through descriptive statistics and the independent samples t-test it was found that there was no statistically significant difference between those in the control and experiment groups. At the end of the treatment, their progress and potential differences between the two groups were checked using the t-test.

\section{Results}

In order to analyze the collected data, the statistical package for social sciences (SPSS 23) was run. Table 1 represents a summary of descriptive statistics from the pretest for both experimental and control groups, $\mathrm{M}=$ 13.80, $\mathrm{SD}=5.93 ; \mathrm{M}=12.80, \mathrm{SD}=5.11$, respectively.

Table 1. Mean Scores on the Pretest for Both Experimental and Control Groups

\begin{tabular}{|l|c|c|c|c|}
\hline & $\mathrm{N}$ & Mean & Std. Deviation & $\begin{array}{c}\text { Std. Error } \\
\text { Mean }\end{array}$ \\
\hline $\begin{array}{l}\text { Experimental } \\
\text { Control }\end{array}$ & 25 & 13.80 & 5.93 & 1.18 \\
\cline { 2 - 5 } & 25 & 12.80 & 5.11 & 1.02 \\
\hline
\end{tabular}

As it appears, there was a slight difference between the mean scores of the control group and the experimental group. In order to make sure both groups were not significantly different, an independent samples t-test was run.

The results in Table 2 show that the difference was not statistically significant, $\mathrm{t}=-.63, \quad \mathrm{p}=.52$. In other words, the experimental group and the control group turned out to be similar in terms of their knowledge vocabulary as tested by the pretest. Thus, both groups proved to be homogeneous in this respect.

Table 2.Results of Independent samples $t$-Test for the Pretest

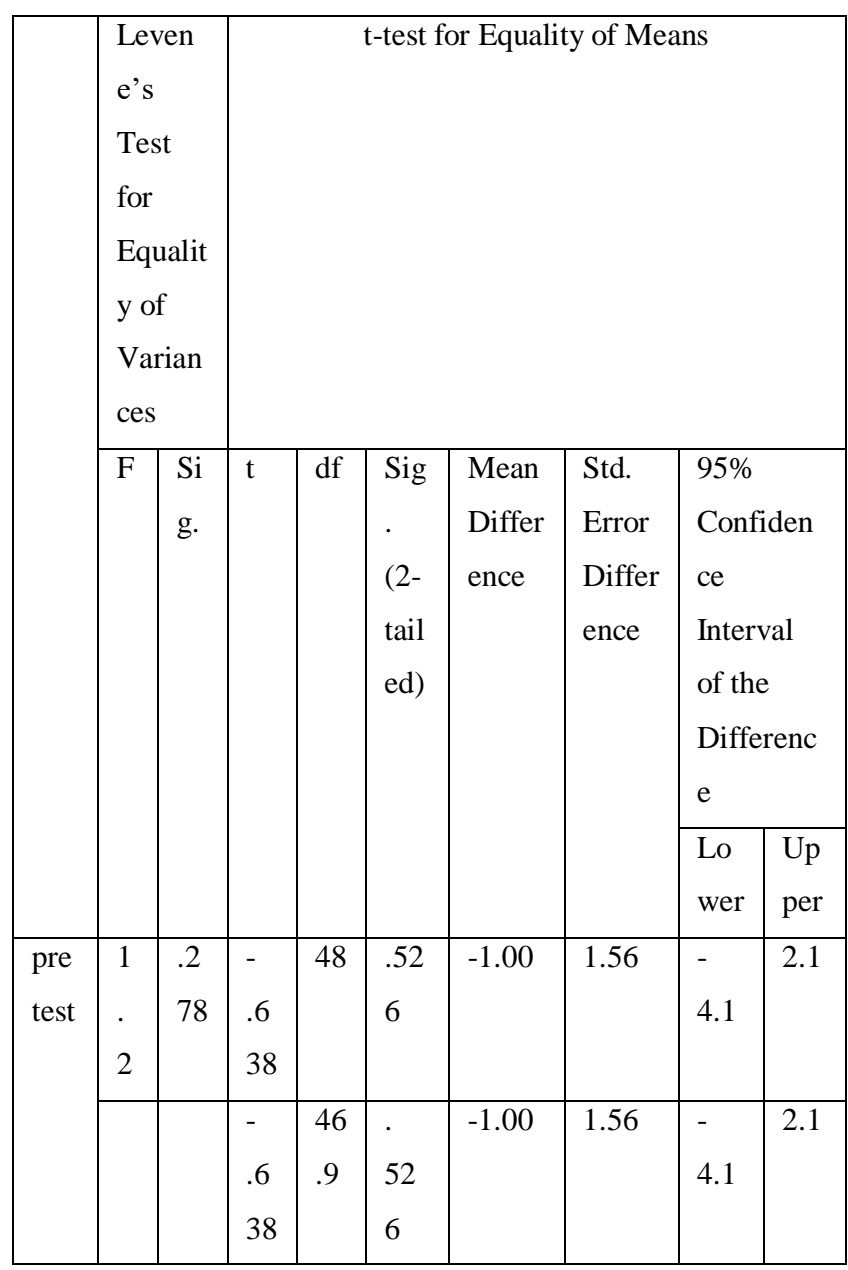

After the instruction period came to an end, in order to find about the extent to which the learners improved their knowledge of vocabulary and also the possible difference between the control and experimental groups the posttest was administered to both groups. The following results were obtained as presented in Table 3 . 
https://doi.org/10.31426/ijamsr.2018.1.7.716

\section{International Journal of Advanced Multidisciplinary Scientific Research (IJAMSR) ISSN:2581-4281}

Table 3. Mean Scores of the Experimental and Control Groups on the Posttest

\begin{tabular}{|l|c|c|c|c|}
\hline & $\mathrm{N}$ & Mean & $\begin{array}{c}\text { Std. } \\
\text { Deviation }\end{array}$ & $\begin{array}{c}\text { Std. Error } \\
\text { Mean }\end{array}$ \\
\hline $\begin{array}{l}\text { Cont. } \\
\text { Pretest } \\
\text { Cont. } \\
\text { Posttest }\end{array}$ & 25 & 12.80 & 5.11 & 1.02 \\
\cline { 2 - 5 } & 25 & 14.36 & 3.22 & .64 \\
\hline Exp. Pretest & 25 & 13.80 & 5.93 & 1.18 \\
\hline $\begin{array}{l}\text { Exp. } \\
\text { Posttest }\end{array}$ & 25 & 20.72 & 2.80 & .56 \\
\hline
\end{tabular}

Note. Exp.= Experimental, Cont. $=$ Control

As the results in Table 3 revealed, there appeared to be differences between the performances of the participants on the pre and posttests in both groups. While in the control group on the pretest a mean score of $12.80(\mathrm{SD}=$ 5.11) was obtained, on the protest there was some improvement, $\mathrm{M}=14.36(\mathrm{SD}=3.22)$. As for the experimental group, such improvement was observed, too. On the pretest, they got a mean score of 13.80 (SD $=$ 5.93), while on the posttest, this group obtained a mean score of $20.72(\mathrm{SD}=2.80)$.

In other words, both the control and experimental groups proved to have improved as a result of instruction. However, in order to check whether there were significantly different as a result of different teaching conditions, the independent samples t-test was then performed. The results are presented in Table 4 .
Table 4. Results of Independent Samples t-Test for the Posttest

\begin{tabular}{|c|c|c|c|c|c|c|c|c|c|}
\hline \multicolumn{3}{|c|}{$\begin{array}{l}\text { Levene's Test } \\
\text { for Equality of } \\
\text { Variances }\end{array}$} & \multicolumn{7}{|c|}{ Equality of Means } \\
\hline & \multirow[t]{2}{*}{$\mathrm{F}$} & \multirow[t]{2}{*}{$\begin{array}{l}\mathrm{Si} \\
\text { g. }\end{array}$} & \multirow[t]{2}{*}{$\mathrm{t}$} & & \multirow[t]{2}{*}{$\begin{array}{l}\text { Sig } \\
\text { (2- } \\
\text { tail } \\
\text { ed) }\end{array}$} & \multirow[t]{2}{*}{$\begin{array}{l}\text { Mean } \\
\text { Diffe } \\
\text { rence }\end{array}$} & \multirow[t]{2}{*}{$\begin{array}{l}\text { Std. } \\
\text { Error } \\
\text { Diffe } \\
\text { rence }\end{array}$} & \multicolumn{2}{|c|}{$\begin{array}{l}95 \% \text { Confi } \\
\text { dence } \\
\text { Interval of } \\
\text { the } \\
\text { Differenc } \\
\text { e }\end{array}$} \\
\hline & & & & & & & & $\begin{array}{l}\text { Lo } \\
\text { we } \\
\text { r }\end{array}$ & $\begin{array}{l}\text { Up } \\
\text { per }\end{array}$ \\
\hline $\begin{array}{l}\text { Equ } \\
\text { al } \\
\text { varia } \\
\text { nces } \\
\text { assu } \\
\text { med }\end{array}$ & $\begin{array}{l}.4 \\
5\end{array}$ & .5 & 7. & 8 & $\begin{array}{l}.00 \\
0\end{array}$ & $\begin{array}{c}- \\
6.36\end{array}$ & .85 & $\begin{array}{l}- \\
8.0\end{array}$ & $\begin{array}{l}- \\
4.6 \\
4\end{array}$ \\
\hline $\begin{array}{l}\text { Equal } \\
\text { varian } \\
\text { ces } \\
\text { not } \\
\text { assum } \\
\text { ed }\end{array}$ & & & 7. & 4 & $\begin{array}{l}.00 \\
0\end{array}$ & $\begin{array}{c}- \\
6.36\end{array}$ & .85 & $\begin{array}{l}- \\
8.0\end{array}$ & $\begin{array}{l}- \\
4.6 \\
3\end{array}$ \\
\hline
\end{tabular}

As shown in Table 4, the results of comparing the mean score of the experimental group and that of the control group indicated a statistically significant difference, $\mathrm{t}=$ 7.43, $\mathrm{p}=0$. In other words, the experimental group outperformed the control group on the vocabulary test after the instruction period. Thus, it appeared that instruction through Telegram was effective. Further explanation follows. 


\section{International Journal of Advanced Multidisciplinary Scientific Research (IJAMSR) ISSN:2581-4281}

\section{Discussion}

Data collection took place in two different classes in Azad University as discussed in the previous section. The results presented within the present paper refer to two classes in the above mentioned schools and their English teachers. The classroom audio- recordings were analyses both quantitatively - counting the number of code switching occasions and qualitatively, analyzing the interactions and identifying the functions of the occurring code switches. As regards first English class, classroom language use in dominated by the almost exclusive use of the target language. English lessons were of a communicative nature as the aim of these lessons was to prepare students for their midterm exam. From the point of view of teacher talk, there are no instances of code switching on the part of teachers during any of the classes observed. Concerning student talk, it is mostly characterized by target language use. In the case of second class, classroom language use is also characterized by the extensive use of the target language. However, code switching in this class can be observed to be initiated by both the teacher and the students. The majority of the class language use relates to discourse functions such as meaning clarification and meaning confirmation. The topic of the lesson is food and it focuses on discussing about different foods. There is a long discussion about food followed by pictures and solving exercises. More code switches occur in task solving part of the lesson, as there are some unknown foods related words that need to be clarified and checked. The teacher uses the target language most of the time, though she uses Iranian for clarifying meaning. Students speak English to discuss the topic and they only switch to Persian when they do not understand a word. However, the teacher in most cases anticipates and comes before the students in translating and explaining unknown items. Second classroom showed an example of teacher code switching. The teacher uses Persian to explain different foods. Thus, food related words are explained and translated into Persian by the teacher in order to help students to better understand the text. The teacher has a lot of trouble concerning discipline and an important number of code switching instances occur when the teacher scolds her students.

The obtained results revealed that those exposed to the new words through code switching had higher gains as compared to those taught through the routine conventional methods in the class. Hence, presenting vocabulary items via code switching to be effective and can lead to better results.

The results of this study lend support to a study done by Zsuzsanna (2004), which revealed that most of the participants used such code switching due to the specific learning context in which students and the teacher do not have the same language, but they share a language that facilitates them in the EFL teaching and learning process. In a similar study by Cook (2001), Macaro (2001) and Levine (2011), they argued against such a pedagogical practice. Their argument is based on the assumption that the language classroom is a multilingual environment and should treated as such.

In other words, users are provided with the desired meaning immediately without disturbing the reading process, a problem usually caused by stopping to look up words in a dictionary in the printed form.

What can further be done is investigating larger units of language (i.e., idiomatic expression, proverbs) to 
learners at higher levels of language proficiency. It could be illuminative to find out whether code switching can be as effective and appealing when used by more proficient learners struggling with more demanding instances of language.

\section{Conclusion}

This study investigated the reverse transfer of L2 to L1 in the case of code switching. The results of the research revealed that vocabulary learning could be facilitated through explaining the words through code switching. The two classes presented a variety of code switching patterns. in first class, the teacher tries to create an exclusive target language environment within the EFL classroom and by showing her authority over classroom language use, she prohibits or at least stigmatize the use of the students first language. The results of the present study have shown that non-target languages are mostly used for translation or explanation of unknown words, classroom management issues and grammar explanation. Meissner (2004) and Boocz-Barna (2010) suggested that, it is necessary to adapt a multilingual approach in foreign language instruction so that language learners can fully exploit the potentials offered by typological similarities between the languages, an idea that is missing in the case of teachers adopting a strict monolingual linguistic behavior during EFL teaching.In the eyes of some of the actors in the language scene, code-switching is a negative influence for second or foreign language learning, and it seems to suggest linguistic deficiencies. However, a significant percentage seems to disagree and believe it to be useful by making communication easier and enhancing learning of the target language. Resorting to code-switching at key moments during a conversation may help students to continue participating and interacting, and in the end might lead them to regain confidence and learn more and faster. Code-switching should not be encouraged by teachers, but it should not be harshly punished in the initial stages of the learning process. The learners themselves will realize in time their own deficiencies and limitations, and it is through positive reinforcement that the need for switching codes will eventually diminish or disappear altogether.

\section{References}

1) Antòn,M. \& DiCamilla,F.J.(1999). Socio-cognitive functions of L1 collaborative interaction in the L2 classroom. Modern Language Journal, 83, 233-247.

2) Anton, M., \& DiCamilla, F. (2012). Functions of L1 in the Collaborative Interaction of Beginning and Advanced Second Language Learners. International Journal of Applied Linguistics, 2, 160-188.

3) Boocz-Barna, katalin. (2010). Az else idegen nyelvi transzfer vizsgalata a nemet mint masodik idegen nyelvet tanulok szokincs-elsajatitasaban [the investigation of L1 transfer in German as an L3 learners vocabulary acquisition]. In: Navracsics, Judit, ed. Nyelv, beszed, iras. Pszicholingvisztikai tanulmanyok I [language, speech and writing: studies in psycholinguistics, I]. Budapest: Tinta Kiado, 176-184.

4) Chung, H. H. (2006). Code switching as a communicative strategy: A case study of KoreanEnglish bilinguals. Bilingual Research Journal, 30(2), 293-307. http://dx.doi.org/10.1080/ 15235882.2006 .10162878

5) Chan, J. Y. C., H. Cao, P. C. Ching, T. Lee, 2009. 'Automatic Recognition of Cantonese-English CodeMixing Speech'. Computational Linguistics and Chinese Language Processes, September, pp.281304. 


\section{International Journal of Advanced Multidisciplinary Scientific Research (IJAMSR) ISSN:2581-4281}

6) Cook, V. (2001). Using the first language in the classroom. Canadian Modern Language Review/La Revue canadienne des langues vivantes, 57(3), 402423. http://dx.doi. org/10.3138/cmlr.57.3.402

7) Cook, $V$ (eds). (2003). Effects of the Second Language on the First. Clevedon: Multilingual Matters.

8) Copland, F., \& Neokleous, G. (2011). L1 to L2: complexities and contradictions. English Language Teachers Journal, 65, 270-280.

9) Degi Zsuzsanna, (2004). Code switching in the foreign language classroom. Language and discourse.733-742.

10) Degi Zsuzsanna. 2012. Types of multilingualism explored in the Transylvania school context. Jezikoslovlje, 13(2): 645-666.

11) Gardener-Chloros, Penelope. 2009. Code-switching. Cambridge university press.

12) Genesee, F., Paradis, J., \& Crago, M. B. (2004). Dual language development and disorders: A handbook on bilingualism and second language learning. Baltimore, MD: Paul H Brooks Publishing.

13) Gil, G. M., Garau, J. M., \& Noguera, J. S. (2012). A case study exploring oral language choice between the target language and the lls in mainstream CLIL and EFL secondary education. Revista de Linguistica y Lenguas Aplicadas (RLLA), 7, 133-145.

14) Greggio, S., \& Gil, G. (2007). Teacher's and learner's use of code switching in the English as a foreign language classroom: A qualitative study. Linguagem \& Ensino, 10(2), 371-393.

15) Gumperz, J. J. (1982). Discourse Strategies - Studies in interactional sociolinguistics. Cambridge: Cambridge University Press.

16) Inbar-Lourie, O. (2010). English only? The linguistic choices of teachers of young EFL learners. International Journal of Bilingualism, 14, 351-367.
17) Jorda, Maria Pilar Safont. 2005. Third language learners; pragmatic production and awareness. Clevedon: Multilingual Matters.

18) Lanziti, J. R. (2002). Justifying selected uses of the learners' first language in the foreign language classroom within communicative language teaching. Paper presented at the Setting the Agenda: Languages, Linguistics and Area Studies in Higher Education Conference, Manchester.

19) Levine, Glenn, S. 2011. Code choice in the language classroom. Bristol: Multilingual Matters.

20) Liebscher, G. and Dailey-O'Cain, J., 2005. Learner Code-switching in the Content-Based Foreign Language Classroom. The Modern Language Journal [e-journal] 89, (ii). Available through: Academic Search Elite. [Accessed 4 November 2010].

21) Macaro, E. (2001). Analysing Student Teachers' Code-Switching in Foreign Language Classrooms: Theories and Decision Making. The Modern Language Journal, 85, 531-548.

22) Macaro, Ernesto. 2014. Students strategies in response to teachers second language explanations of lexical items. The language learning Journal, 42(1):14-32.

23) Martin-Jones, Marilyn. 2000. Bilingual classroom interaction: A review of recent research. Language Teaching, 33(1): 1-9.

24) Mattsson, A., \& Burenhult-Mattsson, N. (1999). Code-switching in second language teaching of French. Working Papers, 47, 59-72.

25) Meissner, Franz-Joseph. 2004. Transfer und transferieren: anleitungen zum interkomprehensionsunterricht [Transfer and transferring: A guide in teaching intercomprehension]. In: Horst G. Klein and Dorothea Rutke eds. Nevere forschungen zur europaischen interkomprehension [new research for the European intercomprehension]. Aachen: Shaker Verlag, 39-66. 


\section{International Journal of Advanced Multidisciplinary Scientific Research (IJAMSR) ISSN:2581-4281}

26) Moore, D. (2002). Case study: code switching and learning in the classroom. International Journal of Bilingual Education and Bilingualism, 5(5), 279293. http://dx.doi. org/10.1080/13670050208667762.

27) Nunan, D., \& Carter, D. (2001). Teaching English to Speakers of Other Languages. Cambridge:Cambridge University Press

28) Paradis, J., Genesee, F., \& Crago, M. B. (2011). Dual language development and disorders: A handbook on bilingualism and second language learning $\left(2^{\text {nd }}\right.$ ed.). Baltimore, MD: Paul H Brooks Publishing.

29) Rukh, S., Saleem, N., Javeed, H. G. M., \& Mehmood, N. (2014). Students' Attitudes towards Teachers' Code-Mixing/Code-Switching to LI and Its Influence on Their L2 Learning: A Case of Business Students in Sargodha. International Journal of Science and Research, 3(5), 11111116.

30) Sert, O., 2005. Code-switching, The Internet TSL Journal, [online] Available at: http://iteslj.org/Articles/Sert-CodeSwitching.html [Accessed 4 November 2010].

31) Sert, O. (2005). The functions of code switching in ELT classrooms. The Internet TESL Journal, 11(8) /online/. Retrieved on 18 January 2008 from http://www.iteslj.org/Articles/ Sert-Code Switching. Html.

32) Schendl, H., \& Wright, L. (red.) (2011). Codeswitching in early English. Berlin: De Gruyter Mouton.

33) Simon, L. 2001. Towards a new understanding of code-switching in the foreign language classroom. In: R. Jacobson, ed. 2000. Trends in Linguistics: Code-switching Worldwide II. Berlin: Mouton de Gruyter.

34) Thomas, S, G., 2001. Language contact, an introduction. [E-book] Edinburgh: Edinburgh University Press Ltd. Available through: http://books.google.com/. [Accessed 10 December].
35) Wang, X. J. (2006). Code-switching between Mandarin and English in English-dominant environments. ARECLS E- Journal, 3 /online/. Retrieved on 18 January 2008 from http: I //www.ecls.ncl.ac.uk/publish/ARECLS/xiaojingwang. htm.

36) Wei, L., Martin, P., (2009). Conflicts and tensions in codeswitching in a Taiwanese EFL classroom. International Journal of Bilingual Education and Bilingualism. [e-journal] 12 (2), 117-122. Available through: Academic Search Elite. [Accessed 6 November 2010].

37) Yaqubi, B., \& Pourimid, S. (2013). First Language Use in English Language Institutes: Are Teachers Free to Alternate between L1 and L2 as Means of Instruction? The Journal of Teaching Language Skills (JTLS), 4 (4), 127-152.

38) Zabrodskaja, A. (2007). Russian-Estonian code switching in the university. Arizona Working Papers in SLA \& Teaching, 14(1), 123-139. 